for example, be a long period at low water when the level did not change appreciably. The Fourier analysis would predict this feature of the tidal change quite accurately, but would not indicate the precise physical cause (the draining of a large expanse of sandy foreshore) which produces the effect. In the same way the Fourier analysis of the thermal disturbance of the crystal would predict the intensity of $\mathrm{X}$-ray reflexion correctly, but, as information concerning the phases is lacking, the presence of groups could not be predicted.

In discussing the theoretical problem offered by the experiments on background reflexions on Laue photographs, Prof. Max Born inquired whether the phenomena can be explained by the wellestablished theory of scattering or whether new assumptions are necessary. He observed that the fact that Sir William Bragg's formula represents the position of the spots so well, suggests that it should appear as a result of a theory more satisfactory formally, than the assumed presence of small groups of atoms. It seems that an improved theory of the effect of thermal vibrations should provide an adequate explanation of the observations. The important fact emerges that just as the Laue spots, or Bragg reflexions, determine the geometry of the lattice, so the background pattern is a complete image of the main features of the dynamics of the lattice.

The observation of effects similar to those discussed above has been recorded by Charlesby, Finch and Wilman ${ }^{15}$ using the method of electron diffraction. Their experiments show that for molecular crystals, such as anthracene, the thermal vibrations of the lattice produce a background pattern. The effect is somewhat similar to that of a vapour in which all the molecules are oriented and produce a pattern which should reflect the symmetry of the molecule. It appears that the X-ray effect is not identical with that observed with electrons, for some of Mrs. Lonsdale's photographs of benzil do not produce a pattern characteristic of the benzene ring when the crystal is examined in a suitable orientation.

The whole subject of background reflexions is evidently one of very considerable interest and no little complexity; further investigation, both theoretical and experimental, should provide information regarding the structural imperfection of crystals, whether of thermal or other origin.

In preparing this article I have been greatly helped by Sir William Bragg, Mrs. Lonsdale and Sir Lawrence Bragg. It is with pleasure that I acknowledge my debt to them.

${ }^{1}$ Friedrich, Phys. Z., 14, 1082 (1913).

${ }^{2}$ Faxén, Z. Phys., 17, 266 (1923).

${ }^{3}$ Waller, Z. Phy8., 17, 398 (1925).

4 Darwin, Phil. Mag., 27, 315 (1914)

${ }^{5}$ Debye, Ann. Phys., 43, 49 (1914).

${ }^{6}$ Laves and Nieuwenkamp, Z. Kristallogr., 90, 279 (1935). Hendricks, Phys. Rev., 57, 448 (1940).

'Preston, Nature, 142, 569 (1938) ; Proc. Roy. Soc., 167, 526 (1939).

${ }^{8}$ Preston, Nature, 143, 76 (1939); Proc. Roy. Soc., 172, 116 (1939).

- Laval, Bull. Soc. Française Min., 62, 137 (1939). Mauguin and Laval, C.R., 1446, 1512 (1939).

10 Wadlund, Phys. Rev., 53, 843 (1938).

${ }_{11}$ Zachariasen, Phys. Rev., 53, 844 (1938) ; 57, 597 (1940).

12 Raman and Nilakantan, NATUke, 145, 667; 146, 686 (1940); Proc. Ind. Acad. Sci., 11, 405 (1940). Raman and Nath, Proc. Ind. Acad. Sci., 12, 83 (1940).

${ }^{13}$ Knaggs, Lonsdale, Müller and Ubbelohde, Nature, 145, 820 (1940). Lonsdale, Knaggs and Smith, NATuRE, 148, 332 (1940). Lonsdale, NATURE, 146, 806 (1940). Lonsdale, Proc. Roy. Soc (1941). Lonsdale, Robertson and Woodward, Proc. Roy. Soc. in the press; Lonsdale and Smith, Proc. Roy. Soc., in the press. is Bragg, Nature, 146, 509 (1940).

15 Charlesby, Finch and Wilman, Proc. Phys. Soc., 51 (1939).

\title{
CENTENARY OF THE PHARMACEUTICAL SOCIETY
}

THE centenary of the foundation of the Pharmaceutical Society of Great Britain occurred on April 15, 1941. Thirty years ago, congratulating the Society on its seventieth anniversary, NATURE observed that it was "an event of considerable interest, which is not wholly confined to those who practise the art of pharmacy". The same may be said, with emphasis, on the occasion of the centenary. It is no small thing even for an institution to survive ten decades. The mere fact is proof of its stamina and its usefulness ; a hundred years on and how many fall by the way. The Pharmaceutical Society has gone from strength to strength, and it may be said to-day that its place among the nation's useful foundations was never more secure and its service to the State never more highly esteemed or more needed.

Just as among individuals, a man often owes his virility and his good purpose in life to his parents, so does the Pharmaceutical Society owe much to the scholarly Quaker, William Allen, F.R.S., who has been justly called its father, and was its first president. He was the owner of a chemist's shop in Plough Court, Lombard Street, London, and it seems strange that in the days when the practice of pharmacy was in the hands of a heterogeneous mass of tradespeople, most of whom were without scientific knowledge and but poorly equipped with the materials of their business, there should be 
found among them a man of high scientific attainments, a fellow of the Royal Society, one of the founders of the Askesian Society for practical research, who had lectured at the Royal Institution and at Guy's Hospital. Besides all these things, William Allen was confidential adviser to Edward, Duke of Kent, the father of Queen Victoria ; it was on the advice of this City druggist that the Duke consented to place his property in the hands of trustees, the consent being given on condition that William Allen was one of them.

There is little wonder, then, that those members of the craft of pharmacy who were sufficiently enlightened to see the need of organization chose this outstanding personality as their leader; and the Society having been established by a resolution passed at a meeting held at a Strand tavern on April 15, 1841, it is not surprising that with such a man at its head the infant body put down education as the first item on its programme. Before the end of the first year a course of lectures had begun at 17 Bloomsbury Square, which was then, as it is now, the Society's headquarters. The policy was initiated of securing as lecturers men of high standing in their particular branches of science, a policy which has been maintained ever since. A year later, the School of Pharmacy-now recognized as a school of the University of London-was established, and soon a chemical laboratory, the first of its kind in Great Britain and the equal of those existing at that time in Germany and France, was set up. A system of examination was instituted, and in due course there was available to physicians the services of a new class of craftsmen well equipped by training and education for the purpose of their calling.

It was not until the Pharmacy Act, 1852, was passed that statutory recognition was given to those who passed the examinations, and not until 1868 that the Society succeeded in impressing upon Parliament that the best way of protecting the public from the dangers inherent in the mishandling of poisons was to reserve the retail sale of these substances to trained vendors. Even to this day, the practice of pharmacy has never been restricted by legislation, but fortunately the law now furnishes means by which the public can distinguish a pharmacy which is under the management of a qualified person from a shop which is not so managed.

Space does not permit extended references to the valuable work done by the Society in connexion with the production of the "British Pharmacopœia", or to many of its other activities, notably its scientific meetings, directed to the spreading of knowledge among its members. The quality and advanced nature of the research work now undertaken in the College of Pharmacy is seen in recent reports from its several departments. Thus in the pharmaceutical chemistry laboratories investigations have been made with the view of bringing recent developments in our knowledge of carbohydrates into the domain of medical substances by work on specific sugars in immunological work, and promising work has been done in connexion with oestrogens. Investigations made in the Department of Nutrition have shown that the pigeon test still appears to be the least accurate of the biological methods for the determination of the vitamins. In the Department of Pharmaceutics, research work has been directed to the investigation of pharmaceutical apparatus with a view to improvement in design, particularly in respect of small-scale types. In the Department of Pharmacognosy detailed studies have been made of the flowers of the belladonna plant, and examinations have been made of Jamaican and Surinam quassia. Work done in the Department of Pharmacology comes under such headings as the assay of cortical hormone, the pharmacologically active substances liberated by adreginic nerves, the pharmacology of antipyretics of the aromatic amine series, the mechanism of porphyrin excretion, the toxicity of certain bactericides, the pharmacology of eucalyptus oil and the chemical assay of powdered ergot.

The above is but a small selection of the subjects which have occupied the attention of research workers of the Pharmaceutical Society, but it serves to show how truly it has endeavoured to fulfil the obligations placed upon it by the Royal Charter of incorporation to advance the knowledge upon which the art of pharmacy is based. It is a far cry from 1841 to 1941, when one reflects upon the state of pharmacy as it was when the Society was founded and as it is to-day. There has been, of course, a slowing down of research activities since the outbreak of war, mainly because of the reduction in staff. Prof. J. H. Gaddum, director of the Pharmacological Laboratories, undertook an appointment under the Government for the duration of the War, and other members of the Society's staff have also been called to different duties. Nevertheless, useful research work continues to be done in the several departments.

Sufficient has been said to show that the Pharmaceutical Society of Great Britain well merits the congratulations it has received not only from kindred institutions in other countries, but especially from the bodies representative of the medical profession, which recognizes that the debt it owes to pharmacy is a debt owed to the Society. 